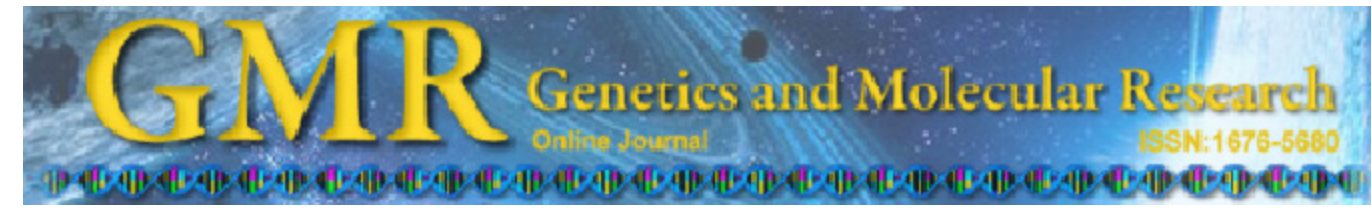

\title{
Is there a cryptic species of the golden snapper (Lutjanus johnii)?
}

\author{
A.B. Adibah and M.N. Darlina \\ School of Biological Sciences, Universiti Sains Malaysia, Penang, Malaysia \\ Corresponding author: M.N. Darlina \\ E-mail: darlinamdn@usm.my \\ Genet. Mol. Res. 13 (4): 8094-8104 (2014) \\ Received July 25, 2013 \\ Accepted March 19, 2014 \\ Published October 7, 2014 \\ DOI http://dx.doi.org/10.4238/2014.October.7.4
}

\begin{abstract}
For centuries, morphology-based fish identification has been applied without molecular evaluation. Many studies showed that specimens with a similar morphology are frequently found to be quite genetically distinct. One of the fish species that still remains taxonomically problematic is a commercial snapper species, Lutjanus johnii. Because of morphological ambiguities among local fish taxonomists in Malaysia, we examined the ability of the cytochrome oxidase I (COI) gene to genetically examine the taxonomic status of L. johnii. A 626-base pair COI region was successfully amplified and aligned with conspecific sequences that were retrieved from GenBank. The phylogenetic tree obtained showed two major clusters; the first cluster consists of L.johnii from Straits of Malacca, Thailand, Australia, and China while the second cluster comprises L. johnii from China and India. The latter group showed sequence divergence greater than $3.5 \%$. After observing this, we suspected that there might be a cryptic species between the South China Sea and Indian Ocean. This is the first molecular report concerning the commercial species of snapper, L. johnii, in Malaysia, which had only gained provisional recognition from morphological examination.
\end{abstract}

Key words: Golden snapper; Lutjanus johnii; Phylogenetics; Cytochrome oxidase I (COI) gene 


\section{INTRODUCTION}

Taxonomy is the foundation of traditional conservation practices (Avise, 1989; Brophy, 2004), and understanding the taxonomic details of a species is central to the development of successful management strategies for sustainable fisheries resources. The basic knowledge of diversity through species discovery and description is mostly complete for some areas of the world and for many families of fishes, but important gaps still remain (Eschmeyer et al., 2010). Consequently, many undescribed species are in potential danger of extinction because of incomplete taxonomy, unrecognized congeneric variation, and/or lack of formal species descriptions (Brophy, 2004). For centuries, morphology-based fish identification has been applied without molecular evaluation. The exploitation of color patterns in fish, for instance, was often used to distinguish closely related species, but several studies (Planes and Doherty, 1997; McMillan et al., 1999) did show the complexity of the relationship between color pattern and genetic divergence. Moreover, specimens with similar morphology are frequently found to be quite genetically distinct, suggesting the involvement of conservative systematic traditions or morphological stasis (Knowlton, 2000). Therefore, morphological distinction alone is inadequate for species identification or for elucidating valid phylogenetic relationships (Grewe et al., 1993; Felsenstein, 2001).

One fish genus that remains taxonomically problematic because of poor studies (Chow and Walsh, 1992; Sarver et al., 1996) is Lutjanus. Species of Lutjanus, which are commonly known as snappers, are widely consumed (Rosmilah et al., 2005) and are highly valued in a number of fisheries of the world (Zhang et al., 2004). Of the 45 species known to date, at least 10 species of Lutjanus are found in coral reefs of Malaysia (Sukarno et al., 1994; Rasidi et al., 1995). One of the most common species available for local consumption is the golden snapper, Lutjanus johnii (Bloch, 1792). Also known as 'jenahak' by locals, this species has an excessive market demand and may fetch a price of up to $\sim$ RM 40.00 per kilogram. Although the morphological characteristics have been outlined and used, the recent application of molecular techniques aid in the revision of the Lutjanus taxonomy, which helps in the discovery of new species in the genus. As examples, Lee and Cheng (1996) discriminated L. ophuysenii from $L$. vitta using allozyme markers, Zhang et al. (2004) identified larvae of the Lutjanus genus using amplified fragment length polymorphisms, and Allen et al. (2013) recently revised L. ruselli and $L$. bitaeniatus and named two new snapper species, $L$. indicus and L. papuensis using the cytochrome c oxidase $1(C O I)$ region.

Recently, the $C O I$ region has been regarded as a promising approach for rapid and accurate identification of species (Armstrong and Ball, 2005). It is used to catalog animal biodiversity (Hebert et al., 2004; Ward et al., 2009) and is one of the most conserved protein-encoding genes in the mitochondrial genome (Brown, 1985). Because of the lack of introns, the COI region has limited exposure to recombination (Saccone et al., 1999) and is more likely to reveal deeper phylogenetic insights than other mitochondrial genes (Lynch and Jarrell, 1993). In this research, we examined the ability of the COI gene to genetically identify the golden snapper from the Straits of Malacca because of the morphological ambiguities of the species among local taxonomists (A. Rahman, Fisheries Research Institution Malaysia, personal communication). We selected the Straits of Malacca as our study site because almost $50 \%$ of the total catches from Malaysia were from the straits [Food and Agriculture Organization (FAO), 2009]. This research aims to accurately identify $L$. johnii and provide baseline genetic data that are required to protect rare or unique genetic stocks that are found in Malaysia. 


\section{MATERIAL AND METHODS}

\section{Samples collection and genomic DNA isolation}

Samples were collected from the Fisheries Development Authority of Malaysia (LKIM) fish landing sites. Morphological confirmation of the species was conducted with the help of expert local taxonomists, FAO-Snappers Identification Catalogue (Allen, 1985), and identification books that were published by the Department of Fisheries Malaysia (Mansor et al., 1998). From each sample, approximately $100 \mathrm{mg}$ fin $\left(1-2 \mathrm{~cm}^{2}\right)$ was dissected and placed in $95 \%$ alcohol. Total genomic DNA from the fin clips was extracted following the salt protocol by the Animal Genomics Laboratory, Liverpool University, United Kingdom (2001) in the presence of proteinase K (Nacalai Tesque, Japan). The preserved DNA pellet was stored at $-20^{\circ} \mathrm{C}$ until use. The degradation of DNA was examined by electrophoresis on $0.8 \%$ agarose gels. DNA quantification and purity were observed using a Q3000 spectrophotometer (Quawell, USA).

\section{DNA amplification}

The 5 ' region of the $C O I$ gene from mitochondrial DNA was amplified from all samples using the FishF1- 5'-TCAACCAACCACAAAGACATTGGCAC-3' and FishR15'-TAGACTTCTGGGTGGCCAAAGAATCA-3' primers by Ward et al. (2005). Polymerase chain reaction (PCR) was carried out in a BIORAD (USA) thermal cycler. The PCR mixture contained $2.5 \mu \mathrm{L}$ 10X PCR buffer, $1.0 \mu \mathrm{L}$ dNTP mixture $(2.5 \mathrm{mM}), 0.25 \mu \mathrm{L} 5 \mathrm{U}$ i-Taq plus DNA polymerase (Intron, Gyeonggi-do, Korea), $2.0 \mu \mathrm{L} \mathrm{MgCl}_{2}(25 \mathrm{mM}), 0.5 \mathrm{pmol}$ of each primer, $10-50 \mathrm{ng}$ DNA template, and ultrapure water to a final volume of $25 \mu \mathrm{L}$. The thermal regime consisted of initial denaturation for $2 \mathrm{~min}$ at $95^{\circ} \mathrm{C} ; 35$ cycles of $94^{\circ} \mathrm{C}$ for $45 \mathrm{~s}, 48^{\circ} \mathrm{C}$ for $45 \mathrm{~s}$, and $72^{\circ} \mathrm{C}$ for $1 \mathrm{~min}$; and a final incubation at $72^{\circ} \mathrm{C}$ for $10 \mathrm{~min}$. PCR products were visualized on $2.0 \%$ agarose gels, and the most intense bands were selected for purification according to the PCR Purification Kit protocol from Genomics Bioscience and Technology (Taiwan). Purified PCR products were sent for sequencing using an ABI3730 sequencing machine provided by the same company.

\section{Data analysis}

The amplified partial COI region of $L$. johnii was used in basic local alignment search tool (BLAST) with the COI gene of the same species using BLASTn from GenBank. All sequences confirmed as L. johnii were then collapsed in haplotypes using the Collapse software version 1.2 (Provan et al., 2005). Haplotypes were aligned using MUSCLE with the Alignment Explorer of the MEGA software version 5.0 (Tamura et al., 2011). The alignments were then subsequently revised by eye in an effort to maximize positional homology. Conspecific COI sequences of L. johnii from China (EF607441, EU600120, EU600121, EU600122), India (EU148537, EU148538), and Australia (EF609396) that were already deposited in GenBank or Barcode of Life Database (BOLD) were compared with the aligned sequences. Sequence divergences were calculated using the Kimura 2-parameter (K2P) distance, clustered by neighbor joining, and bootstrapped using MEGA version 5.0 (Tamura et al., 2011) with 
10,000 replications. A recently described bioinformatic tool, automatic barcode gap discovery (ABGD) (Puillandre et al., 2012) was also employed to detect the breaks in the distribution of genetic pairwise distances called the barcode gap, and the same species, therefore, should be grouped in the same partition. We employed a sequence divergence of $3.5 \%$ as a screening threshold for overlooked species as recommended by Hebert et al. (2004). This is a conservative threshold that approximates 10 times the average within-species $C O I$ sequence variation that is typical of marine fishes (Ward et al., 2005, 2008; Steinke et al., 2009).

\section{RESULTS}

\section{Sample collection}

A total of 39 samples of wild $L$.johnii were caught from nine locations in the Straits of Malacca (Figure 1, Table 1). Four samples from Ranong, Thailand, were obtained from Kuala Perlis fish landing site and were examined in this study for comparison. All samples were photographed and kept as voucher samples in Universiti Sains Malaysia.

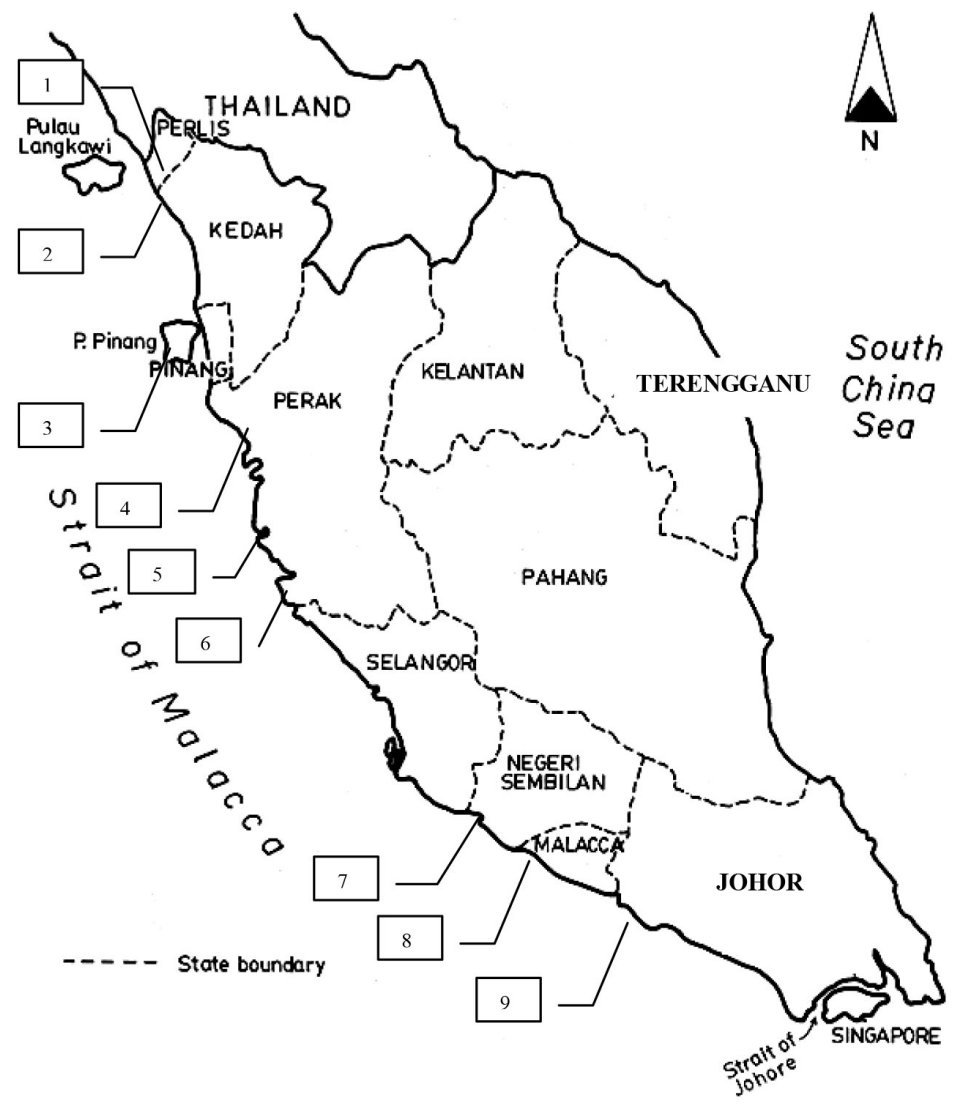

Figure 1. Distribution of locations (box numbered 1 to 9) for the Lutjanus johnii specimens sampled along the Straits of Malacca. Samples from Ranong, Thailand were obtained in Kuala Perlis (box numbered 1) from Thailand fishermen. 
Table 1. Description of sampling locations with coordinates, sample size (N), and animal identity (ID).

\begin{tabular}{|c|c|c|c|c|}
\hline No. & Sampling locations & Coordinates & $\mathrm{N}$ & Animal ID \\
\hline 1 & Kuala Perlis, Perlis & $6^{\circ} 24^{\prime} 01^{\prime \prime} \mathrm{N} ; 100^{\circ} 7^{\prime} 49^{\prime \prime} \mathrm{E}^{*}$ & 3 & KP1-KP3 \\
\hline 2 & Kuala Kedah, Kedah & $6^{\circ} 08^{\prime} 00^{\prime \prime} \mathrm{N} ; 100^{\circ} 18^{\prime} 0^{\prime \prime} \mathrm{E}$ & 7 & $\mathrm{~J} 1-\mathrm{J} 7$ \\
\hline 3 & Teluk Kumbar, Pulau Pinang & $5^{\circ} 17^{\prime} 20^{\prime \prime N}$; $100^{\circ} 13^{\prime} 30^{\prime \prime E}$ & 3 & TK1-TK3 \\
\hline 4 & Kuala Gula, Perak & $4^{\circ} 55^{\prime} 57.79^{\prime \prime} \mathrm{N} ; 100^{\circ} 27^{\prime} 33.57^{\prime \prime} \mathrm{E}$ & 3 & KG1-KG3 \\
\hline 5 & Lumut, Perak & $4^{\circ} 36^{\prime} 00^{\prime \prime} \mathrm{N} ; 101^{\circ} 4^{\prime} 00^{\prime \prime} \mathrm{E}$ & 2 & IP1-IP2 \\
\hline 6 & Kuala Sepetang, Perak & $4^{\circ} 50^{\prime} 18.78^{\prime \prime} \mathrm{N} ; 100^{\circ} 38^{\prime} 0.44^{\prime \prime} \mathrm{E}$ & 4 & KS1-KS4 \\
\hline 7 & Port Dickson, Negeri Sembilan & $2^{\circ} 25^{\prime} 56.08^{\prime \prime} \mathrm{N} ; 101^{\circ} 54^{\prime} 57.84^{\prime \prime} \mathrm{E}$ & 4 & P1-P4 \\
\hline 8 & Kuala Sungai Baru, Melaka & $2^{\circ} 21^{\prime} 57.12^{\prime \prime} \mathrm{N} ; 102^{\circ} 1^{\prime} 54.46^{\prime \prime} \mathrm{E}$ & 7 & M1-M7 \\
\hline 9 & Sg. Muar, Johor & $1^{\circ} 56^{\prime} 37.51^{\prime \prime} \mathrm{N} ; 102^{\circ} 39^{\prime} 48.60^{\prime \prime} \mathrm{E}$ & 6 & JHR1-JHR6 \\
\hline \multirow[t]{2}{*}{10} & Ranong, Thailand & $6^{\circ} 24^{\prime} 01^{\prime \prime N} ; 100^{\circ} 7^{\prime} 49^{\prime \prime} \mathrm{E}^{*}$ & 4 & R1-R4 \\
\hline & & Total & 43 & \\
\hline
\end{tabular}

*Samples from Ranong, Thailand were obtained from Kuala Perlis from Thailand fishermen.

\section{COI divergence analysis}

A 626-bp COI fragment was successfully amplified for each sample. BLAST analysis for all sequences showed $99 \%$ confirmation that the caught samples were L. johnii. Sixteen unique haplotypes (Table 2) were identified and deposited in the GenBank. One hundred thirty-two variable positions were detected, and 88 positions that were parsimonious were used for phylogenetic analysis. All variable sites were found at the first and third positions of codons. No insertions/deletions, heterozygous sites, or stop codons were detected; thus, all of the amplified sequences represent functional mitochondrial COI sequences.

Table 2. Haplotype distribution among individuals of Lutjanus sp collected from the Straits of Malacca, Malaysia, including four samples from Thailand.

\begin{tabular}{|c|c|c|c|c|c|c|c|c|c|c|c|c|}
\hline Haplotype ID & $\begin{array}{l}\text { Accession } \\
\text { No. }\end{array}$ & $\begin{array}{l}\text { Kuala } \\
\text { Perlis }\end{array}$ & $\begin{array}{l}\text { Kuala } \\
\text { Kedah }\end{array}$ & $\begin{array}{c}\text { Teluk } \\
\text { Kumbar }\end{array}$ & $\begin{array}{c}\text { Kuala } \\
\text { Gula }\end{array}$ & Ipoh & $\begin{array}{c}\text { Kuala } \\
\text { Sepetang }\end{array}$ & $\begin{array}{c}\text { Port } \\
\text { Dickson }\end{array}$ & $\begin{array}{c}\text { Kuala Sg. } \\
\text { Baru }\end{array}$ & Muar & Ranong & Total \\
\hline H1 & KF303578 & 1 & 4 & 1 & 2 & 1 & 1 & & 2 & 3 & & 15 \\
\hline $\mathrm{H} 2$ & KF303580 & 1 & 1 & & & 1 & 1 & 2 & & & 2 & 8 \\
\hline $\mathrm{H} 3$ & KF303581 & 1 & & & & & & & & & 1 & 2 \\
\hline $\mathrm{H} 4$ & KF303573 & & 1 & 1 & & & 1 & & & & & 3 \\
\hline H5 & KF303568 & & 1 & & & & & & & & & 1 \\
\hline H6 & KF303582 & & & & & & & & 1 & & 1 & 2 \\
\hline $\mathrm{H} 7$ & KF303569 & & & & & & & & 1 & & & 1 \\
\hline H8 & KF303570 & & & & & & & & 2 & & & 2 \\
\hline H9 & KF303571 & & & & & & & & 1 & & & 1 \\
\hline $\mathrm{H} 10$ & KF303572 & & & & & & 1 & & & & & 1 \\
\hline H11 & KF303583 & & & 1 & & & & & & 1 & & 2 \\
\hline $\mathrm{H} 12$ & KF303574 & & & & 1 & & & & & & & 1 \\
\hline H13 & KF303575 & & & & & & & 1 & & & & 1 \\
\hline H14 & KF303576 & & & & & & & 1 & & & & 1 \\
\hline H15 & KF303579 & & & & & & & & & 1 & & 1 \\
\hline H16 & KF303577 & & & & & & & & & 1 & & 1 \\
\hline Total & & 3 & 7 & 3 & 3 & 2 & 4 & 4 & 7 & 6 & 4 & 43 \\
\hline
\end{tabular}

On a regional scale, the genetic variation at the COI gene in the haplotypes that were obtained was below the intra-species variation threshold $(3.5 \%)$ of marine fishes, which ranged between 0.2 and $1.7 \%$ (Table 3 ). In contrast, comparisons between populations of different localities varied from a low of $0.02 \%$ to a high of $21.7 \%$ (Table 3 ). Value greater than $3.5 \%$ (threshold value) suggested an overlooked or congeneric species of $L$. johnii. The average $\mathrm{K} 2 \mathrm{P}$ nucleotide divergence was $8.1 \%$ with two partitions of distance values obtained from the ABGD analysis (Figure 2). 


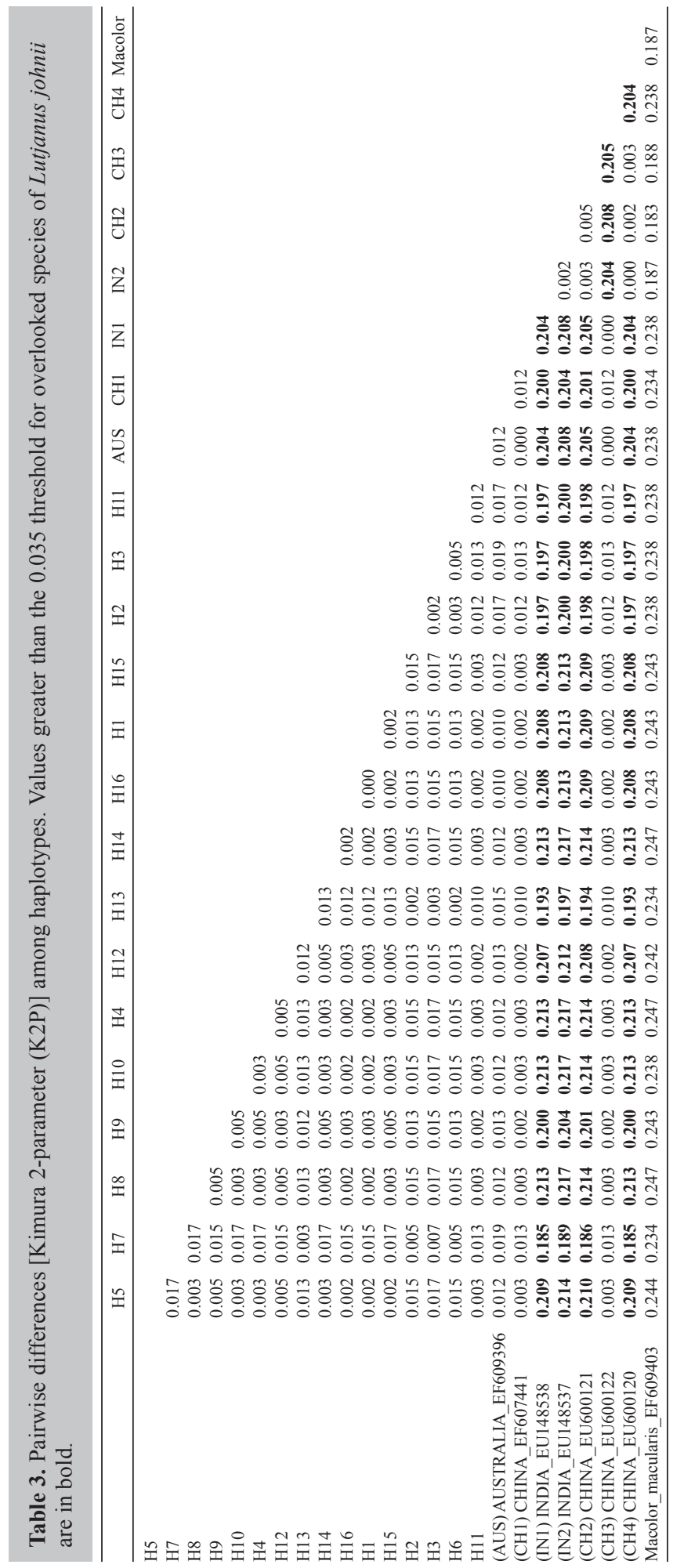




\section{Histogram of distance}

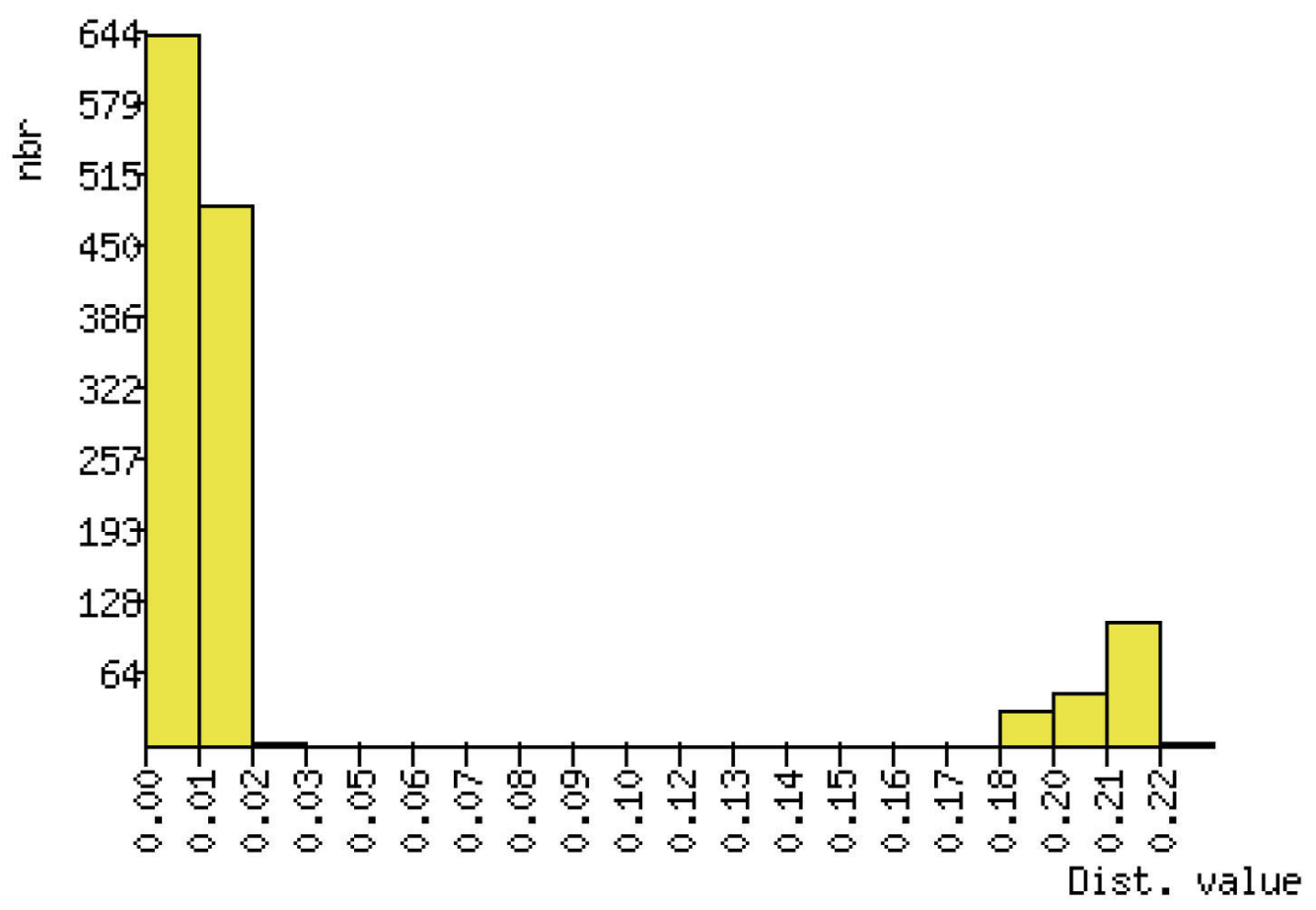

Figure 2. ABGD analysis of barcode gap for Lutjanus johnii pairwise differences.

\section{Phylogenetic analysis}

Sixteen local L. johnii haplotypes were discovered after collapsing the aligned sequences. The integration of the 16 haplotypes with the retrieved GenBank sequences of the species produced two clusters of samples with $100 \%$ bootstrap support. The first cluster comprised L. johnii from Straits of Malacca, Thailand, Australia, and China, which were further divided into four lineages. The first lineage contained a mixture of haplotypes from the Straits of Malacca (H1, H4-H5, H8-H12, and H14-H16) and China, the second lineage contained $L$. johnii haplotypes from Australia, the third lineage contained a mixture of Straits of Malacca and Thailand haplotypes (H2, H3, H6, and H13), and the fourth lineage comprised a sample from Sg. Baru (Straits of Malacca). The second cluster, however, only consisted of L. johnii from India and China. All haplotypes were clearly distinguished from the outgroup species, Macolor macularis (Figure 3). 


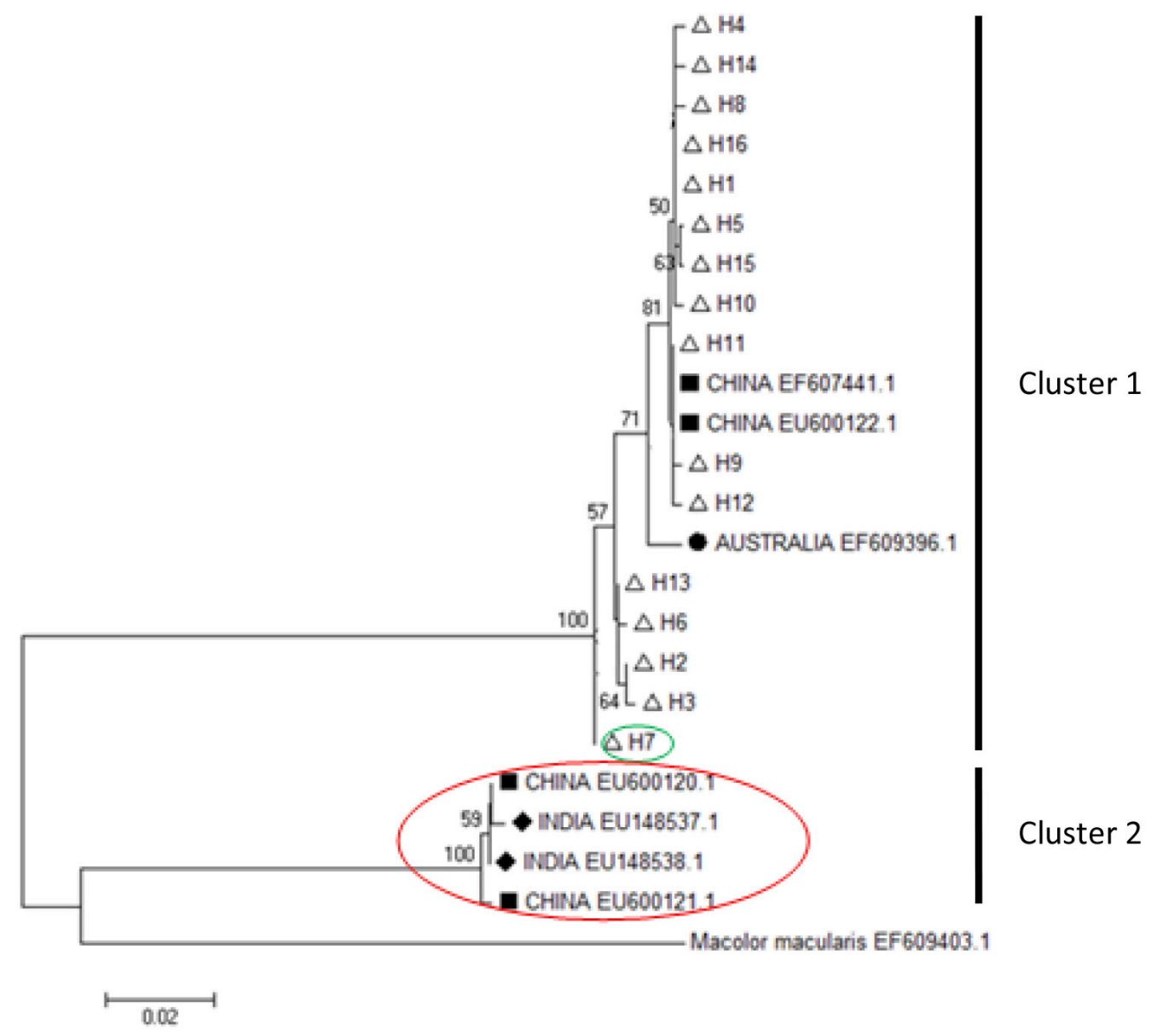

Figure 3. Neighbor-joining tree (K2P distance) of COI Lutjanus johnii haplotype sequences from Malaysia and conspecific sequences (Australia, China, and India) obtained from GenBank. Only bootstrap values greater than 50 are shown.

\section{DISCUSSION}

Morphological ambiguities of L. johnii (Rahman, Fisheries Research Institute Malaysia, personal communication) led us to implementing a molecular approach to facilitate species identification. We selected the COI gene for species discovery as suggested by Ward et al. (2009), which was employed in many studies where traditional methods could not be applied. The phylogenetic analysis of a successfully amplified 626-bp fragment of the COI gene from $L$. johnii did not indicate a monophyletic cluster with conspecific sequences (retrieved from GenBank) from other localities as expected. Rather, two major clusters were apparent. The first cluster consisted of L. johnii from Straits of Malacca, Thailand, Australia, and China while the second cluster comprised L. johnii from China and India. This result was supported by the ABGD analysis, which showed two partitions of distance values. 
The first major cluster was similar to pattern 1, which supports the Hubert et al. (2012) theory that species with Indo-Pacific ranges remain widely distributed. In this cluster, four lineages were visible. The first lineage contained haplotypes that were shared by samples from Straits of Malacca and China, the second lineage included an Australian L. johnii sample, the third lineage comprised Straits of Malacca and Thailand samples, and only a sample from Kuala Sg. Baru was placed in the fourth lineage. The K2P distances observed were less than 10 times the average intraspecies distance for the group under study; thus, no overlooked species were discovered. Similar findings were also observed for other lutjanine species. For example, Blaber et al. (2005) showed that the snappers (L. malabaricus and L. erythropterus) were widely distributed between eastern Indonesia and northern Australia using mitochondrial DNA and allozyme genetic markers, and Wang et al. (2010) reported that an Australian $L$. malabaricus (EF609398) was found clustered together with the South China Sea (SCS) conspecific samples the using COI gene, cytochrome c oxidase subunit II, cytochrome b, and two nuclear markers (recombination activating gene 1 and 2), thus confirming direct evidence of large-scale dispersal and gene flow.

We would like to highlight the discovery of the first and third lineages, which might support the hypothesis by Kimura et al. (2009) and Satapoomin (2011), who suggested that shared stocks of snapper species from SCS and Indian Ocean can occur in the straits because of the existence of a connection through the Straits of Malacca. This agrees with our discovery of shared haplotypes of $L$. johnii samples from Straits of Malacca, China, and Thailand. Although the Straits of Malacca is considered to influence species mixtures between two major oceans (SCS and the Indian Ocean), water current from the strait does not flow throughout the entire Andaman Sea (Rizal et al., 2010). The SCS only influences organisms in the southern part of the Andaman Sea, while the organisms in northern part of the Andaman Sea will be more influenced by water currents from the Indian Ocean via the northern Bay of Bengal (Satapoomin, 2007). Thus, haplotypes shared in samples obtained from Ranong, Thailand, which is situated near the southern part of the Andaman Sea, supported the theory. While gene flow between or among localities in the Straits of Malacca, SCS, and Indian Ocean are still not known to be continuous, our research aids in giving a baseline genetic notion of the L. johnii population in the Straits of Malacca for future justification of the resource management and conservation.

On the other hand, the second major cluster, which contained mixed haplotypes from India and China, indicated the population disjunction of L. johnii and morphological ambiguities, which might result in the discovery of cryptic species between the SCS and Indian Ocean. The former opinion may have important biogeographic implications as suggested by Klangnurak et al. (2012), who reported that the Pleistocene variations in sea levels across Southeast Asia may be an important factor in gene flow restriction in organisms from the Indian Ocean to the SCS. That study used eight microsatellite markers that discriminated L. russelli (Russell's snapper) of Peninsular Thailand into the SCS (Gulf of Thailand) and Indian Ocean (Andaman Sea) groups. The separation of snapper species between the two oceans including $L$. johnii was also done by Wang et al. (2010). However, the finding was not discussed in detailed because the report focused on color polymorphism with the speciation of snapper species in the SCS. Although the Indian L. johnii sequence that was used in this study appeared to be representative of the Indian Ocean biota, clustering with the haplotypes from China support the latter judgement. The voucher samples of L. johnii from India and China need to be reexamined because the morphological ambiguities might mislead the researcher in identifying 
the samples as L. johnii. Because the sequences from China and India exceeded the $3.5 \%$ sequence divergence threshold, we suspected that there was an overlooked species in L.johnii. We also aligned these sequences with other lutjanine species. Surprisingly, the sequences from China and India formed a new group that was close to L. monostigma sequences that were available in GenBank (GenBank accession Nos. JF952788, and JQ350095-JQ350098) (data not shown). We suspected that there might be a cryptic species between the Indian Ocean and SCS after observing this. More research needs to be conducted using additional genetic markers to further confirm the discovery. Taxonomic re-evaluation is therefore recommended for this species if explicit partitioning still exists.

Prior to this study, no public records of L. johnii from Malaysia (Straits of Malacca) were available in GenBank or BOLD. This is the first molecular report concerning a commercial species of snapper, L. johnii, in Malaysia, which only gained provisional recognition from morphological examination. The COI gene, which was used in this research helped to corroborate the likely species status of $L$. johnii and serve as a basis for future studies possibly involving the conservation and management of the species.

\section{ACKNOWLEDGMENTS}

Research supported by the Universiti Sains Malaysia, Short Term Grant USM \#304/ PBIOLOGI/6312027 and the Research University (Individual) Grant USM \#1001/PBIOLOGI/815087.

\section{REFERENCES}

Allen GR (1985). FAO species catalogue. Volume 6. Snappers of the world. An Annotated and Illustrated Catalogue of Lutjanid Species Known to Date. Food and Agriculture Organization of the United Nations, Rome.

Allen GR, White WT and Erdmann MV (2013). Two new species of snappers (Pisces: Lutjanidae: Lutjanus) from the Indo-West Pacific. JOSF 6: 33-51.

Animal Genomics Laboratory, Liverpool University, United Kingdom (2001). Animal Genomics Laboratory, Liverpool University, United Kingdom. Available at [http://sciencepark.mdanderson.org/mbcore/protocols.html]. Accessed June 12, 2011.

Armstrong KF and Ball SL (2005). DNA barcodes for biosecurity: invasive species identification. Philos. Trans. R. Soc. Lond. B Biol. Sci. 360: 1813-1823.

Avise JC (1989). A role for molecular genetics in the recognition and conservation of endangered species. Trends Ecol. Evol. 4: 279-281.

Blaber SJM, Dichmont CM, Buckworth RC and Badrudin B (2005). Shared stocks of snappers (Lutjanidae) in Australia and Indonesia: integrating biology, population dynamics and socio-economics to examine management scenarios. Rev. Fish Biol. Fish. 15: 111-127.

Brophy TR (2004). Geographic variation and systematic in the south-east Asian turtles of the genus Malayemys (Testudines: Bataguridae). Hamadryad 29: 63-79.

Brown WM (1985). The Mitochondrial Genome of Animals. In: Molecular Evolutionary Genetics (MacIntyre R, ed.). Plenum, New York, 95-130.

Chow S and Walsh PJ (1992). Biochemical and morphometric analyses for phylogenetic relationships between seven snapper species (subfamily Lutjaninae) of the western Atlantic. Bull. Mar. Sci. 50: 508-519.

Eschmeyer WN, Fricke R, Fong JD and Polack DA (2010). Marine fish diversity: history of knowledge and discovery (Pisces). Zootaxa 2525: 19-50.

Felsenstein J (2001). Taking variation of evolutionary rates between sites into account in inferring phylogenies. J. Mol. Evol. 53: 447-455.

Food and Agriculture Organization (FAO) (2009). Report No. 940. Second Workshop On The Assessment of Fishery Stock Status in South and Southeast Asia. Bangkok. 
Grewe PM, Krueger CC, Aquadro CF and Bermingham E (1993). Mitochondrial DNA variation among lake trout (Salvelinus namaycush) strains stocked into Lake Ontario. Can. J. Fish. Aquat. Sci. 50: 2397-2403.

Hebert PDN, Stoeckle MY, Zemlak TS and Francis CM (2004). Identification of birds through DNA barcodes. PLoS Biol. 2: $1657-1663$.

Hubert N, Meyer CP, Bruggemann HJ and Guérin F (2012). Cryptic diversity in Indo-Pacific coral-reef fishes revealed by DNA-barcoding provides new support to the centre-of-overlap hypothesis. PLoS One 7: e28987.

Kimura S, Satapoomin U and Matsuura K (2009). Fishes of Andaman Sea: West Coast of Southern Thailand. The National Museum of Nature and Science, Tokyo.

Klangnurak W, Phinchongsakuldit J and James T (2012). Population structure and genetic connectivity of Lutjanus russelli (Lutjanidae) in Thailand. Proceedings of the 12th International Coral Reef Symposium, Cairns.

Knowlton N (2000). Molecular genetic analyses of species boundaries in the sea. Hydrobiologia 420: 73-90.

Lee SC and Cheng HL (1996). Genetic difference between two snappers, Lutjanus ophuysenii and L. vitta (Teleostei: Lutjanidae). Ichthyol. Res. 43: 340-344.

Lynch M and Jarrell PE (1993). A method for calibrating molecular clocks and its application to animal mitochondrial DNA. Genetics 135: 1197-1208

Mansor MI, Kohno H, Ida H and Nakamura HT (1998). Field Guide to Important Commercial Marine Fishes of the South China Sea. SEAFDEC-MFRDMD/SP/2, Kuala Terengganu.

McMillan WO, Weigt LA and Palumbi SR (1999). Color pattern evolution, assortative mating, and genetic differentiation in brightly colored butterflyfishes (Chaetodontidae). Evolution 53: 247-260.

Planes S and Doherty PJ (1997). Genetic relationships of the colour morphs of Acanthochromis polyacanthus (Pomacentridae) on the northern Great Barrier Reef. Mar. Biol. 130: 109-117.

Provan J, Wattier RA and Maggs CA (2005). Phylogeographic analysis of the red seaweed Palmaria palmata reveals a Pleistocene marine glacial refugium in the English Channel. Mol. Ecol. 14: 793-803.

Puillandre N, Lambert A, Brouillet S and Achaz G (2012). ABGD, Automatic Barcode Gap Discovery for primary species delimitation. Mol. Ecol. 21: 1864-1877.

Rasidi A, Ahmad A, Rosli M and Rosdi MN (1995). The Potential of Recreational Fishing in the Marine Park Zones and Artificial Reefs. 5th Fisheries Research Conference at Fisheries Research Institute, Penang.

Rizal S, Setiawan I, Iskandar T and Ilhamsyah Y (2010). Current simulation in the Malacca Straits by using threedimensional numerical model. Sains Malaysiana 39: 519-524.

Rosmilah M, Shahnaz M, Masita A, Noormalin A, et al. (2005). Identification of major allergens of two species of local snappers: Lutjanus argentimaculatus (merah/red snapper) and Lutjanus johnii (jenahak/golden snapper). Trop. Biomed. 22: 171-177.

Saccone C, De Giorgi C, Gissi C, Pesole G, et al. (1999). Evolutionary genomics in Metazoa: the mitochondrial DNA as a model system. Gene 238: 195-209.

Sarver SK, Freshwater DW and Walsh PJ (1996). Phylogenetic relationships of western Atlantic snappers (family Lutjanidae) based on mitochondrial DNA sequences. Copeia 1996: 715-721.

Satapoomin U (2007). A Guide to Reef Fishes of the Andaman Sea, Thailand. Puket Marine Biological Center. World Offset Co., Ltd, Thailand.

Satapoomin U (2011). The fishes of southwestern Thailand, the Andaman Sea-a review of research and a provisional checklist of species. Phuket Mar. Biol. Center Res. Bull. 70: 29-77.

Steinke D, Zemlak TS and Hebert PD (2009). Barcoding nemo: DNA-based identifications for the ornamental fish trade. PLoS One 4: e6300.

Sukarno W, Raja Muhamad Nordin RO, Che Omar MH and Rosdi MN (1994). Tukun Tiruan Malaysia. Jabatan Perikanan Malaysia. Percetakan Nasional Malaysia Berhad, Kuala Terengganu.

Tamura K, Peterson D, Peterson N, Stecher G, et al. (2011). MEGA5: molecular evolutionary genetics analysis using maximum likelihood, evolutionary distance, and maximum parsimony methods. Mol. Biol. Evol. 28: 2731-2739.

Wang Z, Guo Y, Tan W, Li L, et al. (2010). DNA barcoding, phylogenetic relationships and speciation of snappers (genus Lutjanus). Sci. China Life Sci. 53: 1025-1030.

Ward RD, Zemlak TS, Innes BH, Last PR, et al. (2005). DNA barcoding Australia's fish species. Philos. Trans. R. Soc. Lond. B Biol. Sci. 360: 1847-1857.

Ward RD, Holmes BH and Yearsley GK (2008). DNA barcoding reveals a likely second species of Asian sea bass (barramundi) (Lates calcarifer). J. Fish. Biol. 72: 458-463.

Ward RD, Hanner R and Hebert PD (2009). The campaign to DNA barcode all fishes, FISH-BOL. J. Fish Biol. 74: 329-356.

Zhang JB, Huang LM and Huo HQ (2004). Larval identification of Lutjanus Bloch in Nansha coral reefs by AFLP molecular method. J. Exp. Mar. Biol. Ecol. 298: 3-20. 